\title{
AIDS arrives in Soviet Union - (Official)
}

\section{- Health authorities issue warnings to people Scientists seek research links with West}

\section{London}

THE Soviet Union has made a U-turn on its attitude to AIDS (acquired immune deficiency syndrome). After several years of castigating it as a disease of decadent capitalism - and, on occasion, attributing its origin to US bacteriological warfare experiments that went wrong - the Soviet media have begun publishing interviews with high-level health officials setting out how to avoid contamination. Immediate measures include the establishment of an anonymous AIDS screening facility at Moscow's No. 2 Clinical Infection Hospital, and, apparently, a decision by the authorities not to invoke legal sanctions against those who seek its assistance. (Homosexual acts carry a sentence of up to five years in prison.)

A mass campaign of 'special publications' on AIDS is planned, and there is talk of a telephone 'hotline' information service. The All-Union Ministry of Health is to establish a network of diagnostic laboratories which will ultimately screen the blood of all donors as well as all patients presenting symptoms indicative of AIDS. A massive training scheme for specialists in diagnostic and treatment of AIDS is also planned. A new specialized clinic for AIDS will be established, and the 40-odd institutes working on AIDS have been promised increased funding.

The turnabout is not entirely unexpected. There have been several hints that Soviet doctors and virologists would be interested in cooperating with the West on AIDS research - "in the interests of science". The new AIDS awareness campaign was first disclosed at the end of last year, but the full-scale information campaign seems to have been held up until sufficient test-packs were available to meet the expected demands. Interviewed by the Moscow Literaturnay Gazeta last week, the deputy minister of health, Georgii Khlyabich, castigated Western companies that kept their work on AIDS diagnostics so secret that "we obtained practically no information at all, even though we visited those firms". The Westerners, he implied, were dominated by the profit motive. Soviet scientists, he said, have therefore had to seek their own solution. Intensive research on the "diagnostics amd prophylaxis" of AIDS began in 1985, Khlyabich said, and a Soviet diagnostic preparation is now being produced on an industrial scale. Known as IFA-SPID (SPID - pronounced "speed"
- is the Russian acronym for AIDS) the preparation, which was developed by a team headed by Dr Viktor Zhdanov and Dr O. G. Andzhaparidze, is said to be "identical in sensitivity and effectiveness" with Western analogues.

At the same time, a team at the Institute of Immunology of the Academy of Medical Sciences headed by Dr Rem Petrov is working on a synthetic diagnostic agent, Khylabich said. According to a TASS interview with Petrov, this agent is based on synthetic peptides and known as Peptodskrin. Petrov's team is trying the same approach to develop a vaccine to AIDS.

Until such vaccine is developed, however, (and Khlyabich puts the time scale "at least five years") the main means of AIDS prevention must be what Dr Valentin Pokrovskii of the Central Institute of Epidemiology called "a sober way of life in all its manifestations". Interviewed on Moscow radio, Pokrovskii said that Soviet "social conditions" insure against a major epidemic in the Soviet Union, and urged the advantages of an ordered sexual life. It is those who have had sexual contact with foreigners, he said, who should report for check-up. Mr Gorbachev's campaign against drug addiction and alcoholism, he said, was a major means of AIDS prevention. Pokrovskii said the risk from blood transfusions is negligible, as the Soviet Union buys neither blood nor bloodproducts, and tests on a "sufficient cohort of [Soviet] donors" has revealed no infection with AIDS.

But last October, Zhdanov said that AIDS was first discovered in the Soviet Union two years before in an 11-year-old girl who before contracted it during a blood transfusion, and, according to the Khlyabich interview, Zhdanov fears an eventual incidence in the Soviet Union of one in 100,000 of the population (say, 2,800 cases).

But whatever the scale of the eventual spread of the disease, the AIDS campaign is presenting considerable logistical problems for the Soviet health service. The endemic lack of drugs and equipment has been a major target of Gorbachev's drive of "open" criticism, and the extra burden of the AIDS campaign will fall on a medical supply industry already far behind target in both quality and quantity. Nor is it only AIDS-related equipment and drugs that will be needed - the entire Soviet medical profession will switch over to the use of disposable syringes.

\section{Investment by Japan booms in Europe and US}

\section{London}

While the European Economic Community (EEC) prepared its anti-dumping case against the Japanese semiconductor industry this week and the US trade authorities once more accused the Japanese of breaching trade agreements, a British report disclosed an embarrassingly high level of inward investment by the Japanese in Europe and the United States.

The European anti-dumping suit, presented to a meeting of the General Agreement on Tariffs and Trade (GATT) at the beginning of this week, cites Japan as exporting microchips to Europe at below their market value. The United States has made similar accusations in recent months but has not confined criticisms of Japanese trading practices to the semiconductor industry. There is growing concern among the US trade authorities that the Pacific basin industries are the primary cause of the US trade deficit.

The figures, highlighted in a report by the Royal Institute of International Affairs, show that more than a third of Japanese overseas investment in the past 35 years has been directed at the United States, accounting for a commitment of $\$ 25,290$ million. The figures for Europe are equally stark. In the same period, Japan has poured some $\$ 11,000$ million into Europe - more than 13 per cent of Japan's overseas investment.

The size of the investment in both continents is likely to support the view that Japan is using the finance from its trading surpluses to erode indigenous manufacturing and service industries, thereby further weakening the competitive challenge of the United States and Europe.

But the figures also indicate that the investment has proved to be a valuable source of new jobs, again a situation with which indigenous industry has expressed its unease.

According to the study, Industrial Collaboration with Japan, the United States is "by a long way" the first choice for Japanese investment. By the end of 1984 , there were 370 Japanese manufacturing operations in the United States with much investment being attracted by the overseas marketing efforts of individual states, desperate to create new jobs. By last year, claims the study, more than 20 state governments had individual offices in Tokyo.

Not all have been happy with this approach. Colorado governor Richard Lamm is cited in the report as highly critical of the strategy and the dangers posed to US technology. Bill Johnstone 